\title{
ANALISIS PERATURAN PERDAGANGAN INTERNASIONAL UNIFORM CUSTOMS AND PRACTICE FOR DOCUMENTARY CREDIT (UCPDC) REVISI 600 DALAM TINJAUAN EKONOMI ISLAM
}

\section{ANALYSIS OF INTERNATIONAL TRADE REGULATION OF THE UNIFORM CUSTOMS AND PRACTICE FOR DOCUMENTARY CREDIT (UCPDC) REVISION 600 IN ISLAMIC ECONOMIC REVIEW}

\author{
Rian Alfi1a T.Rifqy Thantawi² \\ 1Jurusan Ekonomi Islam Fakultas Ekonomi Islam Universitas Djuanda, Jl. Tol Ciawi No. 1, Kotak Pos \\ 35 Bogor 16770. \\ ${ }_{2}^{2} J u r u s a n$ Perbankan Syariah Fakultas Ekonomi Islam Universitas Djuanda, Jl. Tol Ciawi No. 1, Kotak \\ Pos 35 Bogor 16770 \\ (DiterimaolehDewanRedaksi:16 -02-2014) \\ (Dipublikasikan oleh Dewan Redaksi:01-06-2015 )
}

\begin{abstract}
Letter of Credit (L/C) is the most popular payment method in the world. International Chamber of Commerce (ICC) issued the Uniform Customs And Practice For Documentary Credit (UCPDC) as a rule to adjust the L/C. Currently prevailing UCPDC is UCPDC revised 600 in 2007 which known as UCP 600.

The method used in this research is descriptive qualitative method. The primary data in this research are all contained in articles of the UCP 600. while secondary data are textbooks, journals, thesis, articles, magazines, newspapers and some data from the website that related to UCP 600, international trade and Islamic jurisprudence.

Based on these results there are at least 5 articles which are contrary to Islamic law. Among them the first is article 4 whichhave problem in the contract. The second is article 5 which prohibits the bank to deal with goods when banks can act as a buyer in a contract variation that allowed in the DSN MUI fatwa. The third is article 7 which allow payment before matching the goods with documents. The fourth is article 13 which requires the issuing bank to pay penalty with interest on a condition.
\end{abstract}

Keyword : Uniform Customs And Practice For Documentary Credit (UCPDC) Revision 600, UCP 600

\section{ABSTRAK}

Letter of Credit (L / C) adalah metode pembayaran yang paling populer di dunia. International Chamber of Commerce (ICC) mengeluarkan Uniform Customs Dan Praktek Untuk Documentary Credit (UCPDC) sebagai aturan untuk menyesuaikan L / C. Saat ini berlaku UCPDC adalah UCPDC revisi 600 pada tahun 2007 yang dikenal sebagai UCP 600 . Metode yang digunakan dalam penelitian ini adalah metode deskriptif kualitatif. Data primer dalam penelitian ini adalah semua yang terkandung dalam pasal-pasal UCP 600 . sedangkan data sekunder adalah buku teks, jurnal, tesis, artikel, majalah, surat kabar, dan beberapa data dari website yang berhubungan dengan UCP 600, perdagangan internasional dan hukum Islam.

Berdasarkan hasil ini setidaknya ada 5 artikel yang bertentangan dengan hukum Islam. Di antara mereka yang pertama adalah pasal 4 masalah whichhave dalam kontrak. 
Yang kedua adalah artikel 5which melarang bank untuk berurusan dengan barang-barang ketika bank dapat bertindak sebagai pembeli dalam variasi kontrak yang diperbolehkan dalam fatwa DSN MUI. Yang ketiga adalah pasal 7 yang memungkinkan pembayaran sebelum mencocokkan barang dengan dokumen. Yang keempat adalah pasal 13 yang mewajibkan bank penerbit untuk membayar denda dengan bunga kondisi.

Kata kunci: Uniform Customs Dan Praktek Untuk Documentary Credit (UCPDC) Revisi 600, UCP 600

Rian Alfi. 2014. Analisis peraturan perdagangan Internasional Uniform Custums and Practice For Documentary Credit (UCPDC) Revisis 600 dalam Tinjauan Ekonomi Islam. Jurnal Nisbah (1): 23-37.

\section{PENDAHULUAN}

Perdagangan internasional terjadi karena berbagai alasan, diantaranya adalah terjadi karena suatu negara membutuhkan barang yang tidak dapat tercukupi oleh penawaran dalam negeri, atau bahkan disebabkan karena tidak tersedianya barang tersebut di dalam negeri. Banyak negara berusaha menspesialisasikan pada satu atau beberapa produk. Dalam 50 tahun terakhir ini perdagangan internasional pun semakin berkembang.

Saat ini perdagangan internasional dilakukan dengan menggunakan jasa perantara bank. Jasa perbankan dipakai agar perdagangan lebih efektif dan efisien. Terdapat banyak instrumen yang disediakan oleh bank yang dapat digunakan dalam menyelesaikan transaksi perdagangan internasional. Dengan memperhatikan segala risiko yang mungkin terjadi dalam perdagangan internasional, banyak importir yang menggunakan sarana Letter of Credit (L/C) yang disediakan oleh bank, dalam menyelesaikan pembayaran. L/C dianggap sebagai sarana yang paling aman dalam melindungi kepentingan pembeli maupun penjual dalam perdagangan internsional. ( Warsidi, 2003 ).

Berkaitan dengan L/C ini, Kamar Dagang Internasional atau Internasional Chamber of Commerce (ICC) yang berkedudukan di Paris telah mengeluarkan aturan yang disebut Uniform Customs and Practices for Documentary Credit
(UCPDC).Dimana UCPDC ini telah terbit sebanyak tiga kali, yaitu revisi 300 pada tahun 1983, kemudian revisi 500 terbit tahun 1993 dan revisi 600 terbit tahun 2007 dan berlaku sampai saat ini. Istilah yang sering dipakai dalam menyebut UCPDC revisi terakhir tahun 2007 ini adalah UCP 600 ( Warsidi, 2003 ). UCP 600 tersebut terdiri dari 39 artikel atau pasal mengenai aturan perdagangan internasional.

Bank sebagai perantara memberikan instrument L/C untuk memenuhi kebutuhan importir dalam melakukan transaksi jual beli. UCP 600 menjadi ketentuan yang mengikat semua pihak yang terlibat dalam L/C, kecuali jika L/C menyatakan dengan tegas bahwa $\mathrm{L} / \mathrm{C}$ tidak mengacu kepada UCP 600. Termasuk bank syariah disini, keterlibatannya dalam perdagangan internasional juga perlu mematuhi aturan yang tertera di UCP 600 yang memang merupakan aturan konvensional.

Sehubungan dengan hal tersebut, perlu diketahui sampai saat ini belum ada satu pun lembaga yang membuat aturan mengenai perdagangan internasional yang sesuai dengan prinsip syariah. Sehingga tidak ada pilihan lain bagi bank syariah untuk mematuhi UCP 600 sebagai pedoman dalam keterlibatanya diperdagangan internasional. Sesuai dengan kaidah fiqih, "Kondisi darurat membolehkan sesuatu yang terlarang" dan kaidah "Apa yang tidak bisa dikerjakan seluruhnya maka jangan ditinggalkan seluruhnya". 
UCP 600 dianggap sebagai aturan yang paling lengkap untuk perdagangan internasional. Namun, sebagai seorang muslim tentu sebaiknya kita harus menelaah secara mendalam karena UCP ini adalah aturan konvensional. Sehubungan dengan hal tersebut perlu penelitian untuk mengetahui artikel-artikel apa saja dalam UCP 600 yang sesuai dengan prinsip syariah dan yang bertentangan dengan prinsip syariah. Sudut padang ekonomi Islam dipakai dalam mencari jawaban atas permasalahan ini.

Allah berfirman dalam Al-Qur'an Surat Al-baqarah ayat 208 yang artinya:

"Hai orang-orang yang beriman, masuklah kamu ke dalam Islam keseluruhan, dan janganlah kamu turut langkah-langkah syaitan. Sesungguhnya syaitan itu musuh yang nyata bagimu."

Kemudian Allah berfirman pula masih dalam surat Al-Baqarah ayat 275 yang artinya:

“.... Padahal Allah telah menghalalkan jual beli dan mengharamkan riba...."

Dari petikan dua ayat di atas tentu menjadi suatu motivasi bagi kita umat Islam untuk taat terhadap aturan Islam secara menyeluruh. Perdagangan internasional atau jual beli internasional adalah kegiatan yang telah Allah halalkan. Namun, melihat UCP 600 merupakan aturan dari lembaga konvensional dalam perdagangan internasional, maka perlu kita teliti artikel-artikel dalam UCP 600 tersebut untuk memilah mana artikel yang tidak bertentangan dengan syariat Islam dan mana yang tidak bertentangan dengan syariat Islam.

Berdasarkan penjelasan di atas dilakukanlah penelitian untuk mengkaji kesesuaian UCP 600 dengan Ekonomi Islam. Dalam menghadapi permalahan ini, keadaan darurat memaksa bank syariah untuk mengikuti UCP 600 sebagai pedoman dalam perdagangan internasional karena UCP 600 dianggap sebagai aturan terlengkap yang pernah ada. Namun karena UCP 600 adalah produk internasional sehingga perlu dilakukan penelitian untuk menganalisis UCP 600 dalam tinjauan ekonomi Islam. Rumusan masalah dalam penelitian ini adalah artikel-artikel apa saja dalam UCP 600 yang tidak sesuai dengan prinsip syariah.

Bertitik tolak dari rumusan masalah yang telah dipaparkan, Penelitian ini dilakukan dengan tujuan untuk mengetahui artikel-artikel dalam UCP 600 yang tidak sesuai dengan Prinsip Syariah.

\section{MATERI DAN METODE}

\section{Kebiasaan Internasional sebagai Sumber Hukum Internasional}

Menurut pasal 38 Piagam Mahkamah Internasional dijelaskan sumber hukum internasional apa saja yang menjadi dasar Mahkamah Internasional dalam mengadili suatu perkara, sumber hukum tersebut antara lain ( Black, 1979 ). (1) Perjanjian Internasional; (2) Prinsip Hukum Umum; (3) Keputusan Pengadilan dan Pendapat Para Sarjana Terkemuka di Duni; dan (4) Kebiasan Internasional.

Suatu kebiasaan internasional dapat dikatakan sebagai sumber hukum internasional apabila terpenuhi dua unsur yang berupa unsur material dan unsur psikologis. Yang dimaksud dengan unsur material adalah harus terdapatnya suatu kebiasaan, yaitu tindakan yang dilakukan berulang-ulang dengan cara yang sama, yang bersifat umum. Sedangkan yang dimaksud dengan unsur psikologis adalah bahwa kebiasaan itu harus diterima sebagai hukum oleh masyarakat internasional yang berhubungan dengan hukum internasional. ( Warsidi, 2003 ).

\section{Letter of Credit}

Letter of Credit (L/C) atau biasa disebut surat kredit berdokumen merupakan alat pembayaran yang dikeluarkan bank atas permintaan importir dalam transaksi dagang internasional ( Nazir, 2004 ) Sedangkan menurut Bank Indonesia, L/C merupakan janji dari issuing bank untuk membayar sejumlah uang kepada eksportir sepanjang ia dapat 
memenuhi syarat dan kondisi L/C tersebut. ( Black, 1979).

$\mathrm{L} / \mathrm{C}$ adalah produk dari ICC yang diatur oleh UCP 600. L/C merupakan salah satu jasa bank dalam hal transaksi perdagangan internasional. Berbeda dengan perdagangan dalam negeri, dalam perdagangan luar negeri dengan menggunakan $\mathrm{L} / \mathrm{C}$, bank akan dihadapkan pada berbagai masalah, seperti (1) letak geografis; (2) hukum dan politik setiap negara yang berbeda; (3) bahasa yang berbeda; (4) mata uang; (5) risiko suatu negara. ( Black, 1979).

Dalam perbankan syariah dikenal juga L/C Syariah. DSN mendefinisikan L/C impor syariah dan L/C ekspor syariah di fatwa yang berbeda.Pada Fatwa DSN 34/DSN-MUI/IX/2002: Letter of Credit (L/C) Impor Syari'ah disebutkan bahwa, Letter of Credit (L/C) Impor Syariah adalah surat pernyataan akan membayar kepada eksportir yang diterbitkan oleh bank untuk kepentingan importir dengan pemenuhan persyaratan tertentu sesuai dengan prinsip syariah.

Kemudian Fatwa DSN 35/DSNMUI/IX/2002: Letter of Credit (L/C) Ekspor Syari'ah: Letter of Credit (L/C) Ekspor Syariah adalah surat pernyataan akan membayar kepada eksportir yang diterbitkan oleh bank untuk memfasilitasi perdagangan ekspor dengan pemenuhan persyaratan tertentu sesuai dengan prinsip syariah.

\section{Perdagangan Internasional Terkini}

Aturan yang berlaku secara umum di dunia perdagangan internasional adalah United Customs and Practices for Documentary Credit (UCP 600). UCP 600 ini merupakan seperangkat kebiasaan dan praktik dalam perdagangan internasional yang dijadikan baku oleh International Chamber of Commerce (ICC), organisasi bisnis dunia yang berbasis di Paris. Saat ini UCPD yang berlaku adalah UCP 600 terbaru revisi 600 atau biasa disebut UCP 600 .

Adapun UCP 600 adalah seperangkat ketentuan yang berlaku terhadap setiap documentary credit (termasuk, hingga perluasan terhadap mana UCP boleh berlaku, setiap Standby Letter of Credit) bila teks credit mengindikasikan secara tegas bahwa credit tunduk pada UCP ini. UCP mengikat kepada semua pihak kecuali dengan tegas dimodifikasi atau tidak diberlakukan oleh kredit. ( ICC, 2007 ).

StanbyLetter of Credit yang dimaksud dalam definisi UCP 600 di atas adalah setiap perjanjian, tanpa memandang apapun namanya atau uraiannya, dimana suatu bank (issuing bank), bertindak atas permintaan dan instruksi seorang nasabahnya (applicant atau atas kemauannya sendiri).

\section{Jenis-Jenis $\mathrm{L} / \mathrm{C}$}

Jenis-jenis $\mathrm{L} / \mathrm{C}$ dikenal menurut pendekatan yang dilakukan menurut penerbitnya, bentuk, syarat, cara pembayaran, hak beneficiary, serta perjanjiannya ( Malayu, 2004 ). Jenis-Jenis L/C tersebut adalah sebagai berikut:

1. Menurut Penerbitnya: (1) Mercant $L / C$; (2)Banker $L / C$

2. Menurut Bentuknya: (1) Revocable $\mathrm{L} / \mathrm{C}$; (2) Irrevocable $\mathrm{L} / \mathrm{C}$; Irrevocable and confirmed $L / C$.

3. Menurut Syarat-Syaratnya: Documentary L/C; (2) Open (clean) $L / C$.

4. Menurut Cara Pembayarannya: (1) Sight $L / C$; (2) Usance (term) $L / C$.

5. Menurut Hak Beneficiary: (1) Transferable L/C; (2) Non-transferable $L / C$.

6. Menurut Perjanjiannya: (1) Restricted (straight) $L / C$; (2) General $L / C$.

7. Menurut Jenis L/C Khusus: (1) Aflopend $L / C$; (2) Revolving $L / C$; (3) Back to back L/C; (4) Red Clause L/C; (5) Green Clause L/C; (6) Negociering $L / C$; (7) Confirmed Negociering $L / C$; (8) Unconfirmed Negociering $L / C$; (9) Standby $L / C$.

1) dokumen-dokumen transaksi impor;

2) Besar ujrah harus disepakati di awal dan dinyatakan dalam 
bentuk nominal, bukan dalam bentuk persentase;

3) Hutang kepada eksportir dialihkan oleh importir menjadi

\section{Pihak-Pihak Yang Terlibat dalam Transaksi L/C}

Dalam transaksi L/C pihak-pihak yang terlibat adalah sebagai berikut:

(Warsidi, 2003)

1. Pemohon (Applicant), yaitu pihak yang memohon untuk diterbitkan $\mathrm{L} / \mathrm{C}$ yang dalam hal ini umumnya adalah pembeli/importir.

2. Bank Penerbit (Issuing Bank), yaitu bank yang atas permintaan Applicant menerbitkan L/C.

3. Penerima (Beneficiary), yaitu pihak kepada siapa L/C diterbitkan/diperuntukkan yang dalam hal ini adalah eksportir.

4. Bank Penerus (Advising Bank), yaitu bank yang melakukan otentikasi atas L/C yang diterima dan menginformasikan beneficiary mengenai penerimaan $\mathrm{L} / \mathrm{C}$ tersebut.

5. Bank yang ditunjuk (Nominated Bank), yaitu bank-bank yang dipilih dalam sales contract seperti misalnya bank yang melakukan negosiasi (selanjutnya disebut negotiating bank), melakukan konfirmasi (selanjutnya disebut confirming bank) dan lainlain.

6. Bank Penegosiasi (Negotiating Bank), yaitu bank yang melakukan negosiasi/pengambil-alihan atas dokumen ekspor dan karenanya membayar terlebih dahulu kepada beneficiary dan untuk selanjutnya menagih pembayaran kepada issuing bank.

7. Bank Pengkonfirmasi (Confirming Bank) yaitu bank yang memberikan konfirmasi atau jaminan kepada beneficiary apabila issuing bank tidak melakukan pembayaran hutang kepada bank dengan meminta bank membayar kepada eksportir senilai barang yang diimpor.

sebagaimana yang diperjanjikan dalam L/C.

\section{Penelitian Terdahulu}

Penelitian terdahulu tentang UCP 600 atau tentang $\mathrm{L} / \mathrm{C}$ syariah dilakukan oleh:

1. Sharifah Faigah Syed Alwi (Centre of Finance ), Uzaimah Ibrahim (Ahmad Ibrahim) \&Mohd Fuad Sawari dari negara Malaysia dengan judul penelitiannya, "An Issue on Uniform Customs and Practice for Documentary Credits (UCP) No 600 for Islamic Letter of Credit"disampaikan pada International Conference on Economics and Business Research 2013 (ICEBR 2013).Tujuan dari makalah ini adalah untuk memperjelas masalah pada beberapa artikel dari UCP 600 sebagai aturan yang mengatur L/CWakalah dan L/C Murabahah. Pada saat yang sama, tulisan ini membahas praktek beberapa bank syariah di Malaysia menghadapi masalah ini.

Sebagai hasilnya, penelitian tersebut menemukan masalah pada UCP 600 untuk L/C Syariah yang adalah masalah kekurangan dalam menangani semata-mata dengan dokumen untuk LC Wakalah dan LC Murabahah tanpa memeriksa kondisi barang. Penelitian tersebut menganalisis dengan menentukan apakah hal tersebut sesuai dengan prinsip syariah. Terakhir, solusi untuk menyelesaikan masalah pada UCP 600 untuk L/C Syariah dianjurkan untuk Bank Negara Malaysia.

2. Ahmad Azam Othman Phd \& Akhtarzaite Abdul Aziz Phd dari International Islamic University Malaysia, dengan judul 
penelitiannya, "Principle of Autonomy in Letter of Credit $(L / C)$ - An Overview From Legal and Shariah Perspective" disampaikan pada International Conference on Economics and Business Research 2013 (ICEBR 2013). Penelitian ini bertujuan ini bertujuan untuk menjelaskan makna prinsip otonomi, sifat dan latar belakang. Pertama menyoroti pentingnya prinsip otonomi dalam transaksi LC. Selanjutnya, membahas kerangka hukum prinsip otonomi mana sampai batas tertentu, perbandingan antara artikel yang relevan di UCP 500 dan 600 yang disorot. Selanjutnya, diskusi berfokus pada kasus-hukum yang relevan di mana prinsip otonomi secara signifikan berlaku dalam transaksi LC. Terakhir, membahas masalah kepatuhan syariah dalam penerapan prinsip ini dalam LC.

Hasil dari penelitian ini adalah konsep otonomi harus dilihat untuk dapat diterapkan dalam kontrak syariah atas (wakalah, murabahah dan musharakah) untuk memastikan kepraktisan serta mempertahankan karakteristik khasnya. Dengan kata lain, otonomi dan prinsip-prinsip syariah harus mampu secara bersamaan berdampingan untuk membentuk holistik L/C Syariah sebagai instrumen untuk menjamin pembayaran oleh bank. Jika hal ini gagal, L/C Syariah akan menjadi tidak menarik hanya karena kewajiban melakukan oleh bank pasti dikompromikan. Hal ini tampaknya untuk menghancurkan maksud dan tujuan dari Instrumen $\mathrm{L} / \mathrm{C}$.

\section{Kerangka Pemikiran}

Dalam meneliti kandungan UCP 600 ini, peneliti mencoba untuk melakukan tinjauan ekonomi Islam terhadap UCP 600 dengan memakai beragam referensi kemudian memisahkan antara bagian mana dari UCP 600 yang sesuai dengan Syariat Islam dan bagian mana yang tidak sesuai dengan Syariat Islam. Hasil penelitian nanti diharapkan akan berguna sebagai masukan bagi dunia perbankan syariah atau lembaga terkait demi meningkatkan kepatuhan umat Islam kepada syariat Islam khususnya di dunia perbankan syariah. Adapun kerangka pemikiran tersebut, dapat digambarkan dalam bagan berikut.

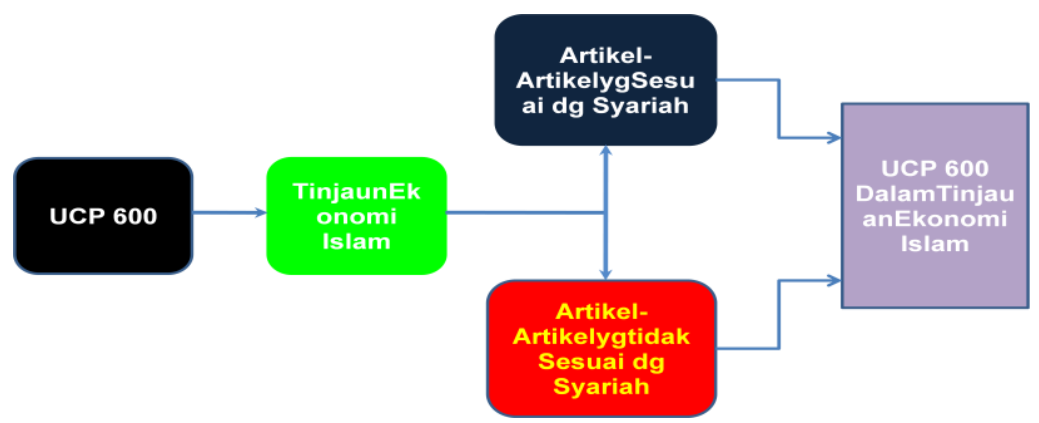

Gambar 1. Kerangka Pemikiran Penelitian

\section{Jenis Penelitian dan Analisis Data}

Jenis penelitian yang dilakukan dalam penelitian ini adalah penelitian deskriptif kualitatif. Objek penelitian ini adalah UCP 600 yang dikeluarkan oleh International Chamber of Commerce tahun 2007. Lebih spesifiknya objek penelitian ini adalah semua pasal yang ada dalam UCP
600.Populasi dalam penelitian ini adalah semua pasal yang terkandung dalam UCP 600. Dan yang menjadi sampel adalah populasi penelitian.

Data primer yang digunakan dalam penelitian ini adalah semua artikel yang terkandung dalam UCP 600 yang telah diterjemahkan dari bahasa Inggris ke bahasa Indonesia. Sedangkan data sekunder dalam penelitian ini bersumber 
dari buku teks, litertatur, materi kuliah, artikel, jurnal, skripsi lain memiliki hubungan serta sumber lain yang berkaitan erat dengan dengan pembahasan masalah ini.

Peneliti mengumpulkan data yang dibutuhkan dengan menggunakan beberapa teknik diantaranya pengumpulan data berupa Dokumen UCP 600 itu sendiri yang diperoleh dari situs International Chamber of Commerce, buku teks dan literatur lain yang menerangkan aturan ekonomi Islam yang berkaitan dengan perdagangan internasional atau yang berhubungan dengan jual beli; penelitian pustaka; dan wawancara.

\section{HASIL DAN PEMBAHASAN}

\section{Hal-Hal yang Dibahas dalam Setiap Artikel UCP 600}

Berikut ini adalah keterangan mengenai hal-hal yang dibahas dalam setiap artikel dalam UCP 600.

1. Artikel 1 : menjelaskan tentang definisi UCP 600.

2. Artikel 2 : menjelaskan pihakpihak yang terlibat dalam $\mathrm{L} / \mathrm{C}$ dan beberapa istilah yang digunakan dalam L/C. Diterangkan definisi dari Advising Bank, Applicant, Banking Day, Benefeciary, Complying presentation, Confirmation, Confirming Bank, Credit, Honour, Issuing Bank, Negotiations, Nominated Bank, Presesntation, dan Presenter.

3. Artikel 3 : menjelaskan tujuan dari UCP 600 berkenaan dengan persyaratan autentitas dan sahnya dokumen, keterangan pengelompokkan cabang bank di negara berbeda ke dalam kelompok bank yang berbeda pula.

4. Artikel 4 : menjelaskan hubungan bank dengan kontrak yang dibuat antara applicant dan beneficiary dan hubungan beneficiary dengan kontrak yang dibuat antara applicant dengan issuing bank.

5. Artikel 5 : menjelaskan bahwa bank-bank hanya berurusan dengan dokumen-dokumen, tidak dengan barang atau jasa.

6. Artikel 6 : menjelaskan kewajibankewajiban yang harus dipenuhi dalam L/C yang berhubungan dengan ketersediaan, tanggal jatuh tempo dan tempat Presentasi L/C.

7. Artikel 7 : menjelaskan tanggung jawab issuing bank.

8. Artikel 8 : menjelaskan tanggung jawab confirming bank.

9. Artikel 9 : menjelaskan tentang penerusan kredit dan perubahannya.

10. Artikel 10 : menjelaskan perubahan $\mathrm{L} / \mathrm{C}$.

11. Artikel 11 : menjelaskan teletransmisi, pre advised credit dan perubahannya.

12. Artikel 12 : menjelaskan kewajiban nominated bank.

13. Artikel 13 : menjelaskan aturan reimbursmen antar bank.

14. Artikel 14 : menjelaskan standar untuk pemeriksaan dokumen.

15. Artikel 15 : menjelaskan kewajiban setelah presentasi yang sesuai.

16. Artikel 16 : menjelaskan dokumen diskrepansi (adanya ketidakcocokan atau ketidaksesuaian pada dokumen), persetujuan yang berkaitan dengannya dan kewajiban dalam pemberitahuannya.

17. Artikel 17 : menjelaskan aturan berkaitan dengan dokumen Asli dan dokumen salinan.

18. Artikel 18 : menjelaskan aturan yang berkaitan dengan commercial invoice.

19. Artikel 19 : menjelaskan dokumen pengiriman barang atau dokumen barang paling sedikit mencakup dua mode transportasi yang berbeda. 
20. Artikel 20 : menjelaskan aturan yang berkaitan dengan bill of lading.

21. Artikel 21 : menjelaskan aturan yang berkaitan dengan nonnegotiable sea waybill.

22. Artikel 22 : menjelaskan aturan yang berkaitan dengan charter party bill of lading.

23. Artikel 23 : menjelaskan tentang pengangkutan barang yang dikirim melalui transportasi udara.

24. Artikel 24 : menjelaskan tentang pengangkitan barang yang dikirim melalui darat (baik dengan kendaraan bermotor ataupun dengan kereta) dan melalui tranportasi air atau laut.

25. Artikel 25 : menjelaskan aturan dalam menggunakan jasa pengiriman (kurir) yang berkaitan dengan kewajiban yang harus ada dalam bukti penerimaan kurir dan kewajiban yang harus ada dalam mengesahan di pos penerimaan barang.

26. Artikel 26 : menjelaskan aturan yang berkaitan dengan klausul pengangkutan barang dan biaya tambahan atas pengangkutan barang.

27. Artikel 27 : menjelaskan bagaimana dokumen pengiriman barang yang bersih.

28. Artikel 28 : menjelaskan aturan yang berkaitan dengan dokumen asuransi pengiriman dan cakupannya.

29. Artikel 29 : menjelaskan aturan tentang perpanjangan jatuh tempo atau hari terakhir untuk prensentasi.

30. Artikel 30 : menjelaskan tentang toleransi dalam nilai kredit, kuantitas dan harga barang.

31. Artikel 31 : menjelaskan tentang dokumen pengiriman barang yang lebih dari satu.
32. Artikel 32 : menjelaskan aturan tentang pengiriman barang yang dilakukan secara bertahap.

33. Artikel 33 : menjelaskan aturan tentang waktu presentasi pada bank.

34. Artikel 34 : menjelaskan pembebasan tanggung jawab kepada bank atas isi dokumen dan keabsahan dokumen.

35. Artikel 35 : menjelaskan pembebasan tanggung jawab bank dalam kesalahan penafsiran istilahistilah teknis dalam dokumen barang atau dalam $\mathrm{L} / \mathrm{C}$.

36. Artikel 36 : menjelaskan kebebasan tanggung jawab bank dalam keadaan force majure.

37. Artikel 37 : menjelaskan kebebasan tanggung jawab bankbank atas intruksinya kepada bank lain.

38. Artikel 38 : menjelaskan aturan tentang tranferable credit atau $\mathrm{L} / \mathrm{C}$ yang bisa diteruskan kepada second beneficiary atau beneficiary lain.

39. Artikel 39 : menjelaskan tentang pengalihan hasil pembayaran oleh beneficiary.

\section{Artikel-Artikel dalam UCP Yang Perlu Dikritisidalam Tinjauan Ekonomi Islam}

Namun L/C syariah ini dihadapkan kepada aturan perdagangan internasional produk dari konvensional yaitu UCP 600 . UCP 600 adalah produk dari ICC dan dirancang untuk memenuhi kebutuhan L/C konvensional. (Sharifah, 2013 ). Ini kenyataan bahwa ICC tidak mengakomodir aturan-aturan perbankan syariah yang diperlukan bagi negara-negara muslim (Chapra, 2007). Atau mungkin karena Islamic Development Bankmelalui OKI belum mengajukan draft tentang aturan $\mathrm{L} / \mathrm{C}$ ini yang sesuai dengan syariah kepada ICC.

Pada dasarnya Islam tidak serta merta menolak aturan dari luar Islam. Tetapi aturan yang berasal dari luar Islam 
namun tidak bertentangan Islam seperti dalam dua kaidah fiqih ini.

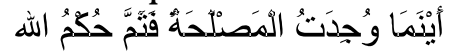

"Di mana terdapat kemaslahatan, di sana terdapat hukum Allah"

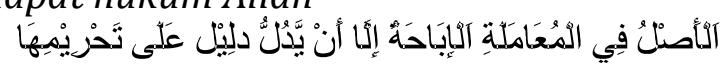

"Hukum asal semua bentuk mu'amalat adalah boleh dilakukan kecuali ada dalil yang mengharamkannya"

Berdasarkan hal tersebut, ditinjau dengan ekonomi Islam artikel-artikel yang terdapat dalam UCP 600 dikategorikan ke dalam dua kategori. Pertama artikel-artikel yang tidak bertentangan dengan aturan Islam dan kedua artikel-artikel yang bertentangan dengan aturan Islam. Artikelartikel yang bertentangan dengan aturan Islam tersebut di antaranya:

\section{Artikel 4 UCP 600}

"Kredit VS Kontrak

(a) Credit menurut sifatnya merupakan transaksi yang terpisah dari kontrak penjualan atau kontak lainnya yang menjadi dasar credit. Bank-banksama sekali tidak memperhatikan atau terikat oleh kontrak Konsekuensinya, janji suatu bank untuk membayar, menegosiasi atau memenuhi setiap kewajiban lainnya berdasarkan credit tidak tunduk pada tuntutan atau pembelaan-pembelaan applicant yang berasal dari hubungannya dengan issuing bank atau beneficiary. (b) Beneficiary sama sekali tidak dapat mengikatkan dirinya atas hubunganhubungan kontraktual antar bank-bank atau antara applicant dan issuing bank."

\section{Analisis Issuing Bank sebagai Wakil dari Applicant dalam Lalu Lintas Pembayaran}

Pada artikel 4 poin a diatas, disebutkan bahwa bank-bank tidak terikat oleh kontrak jual beli antara ekportir dan importir. Namun, sesuai dengan hukum wakalah itu sendiri, bahwa objek yang diwakilkan tidak boleh bertentangan dengan syariah Islam. Untuk menghindari hal ini, kegiatan impor yang melibatkan bank syariah dengan L/C impor syariah, tentu hanya akan dilakukan jual beli yang sesuai syariah. Langkah DSN dalam mengeluarkan fatwa L/C impor yang salah satunya dengan menggunakan akad wakalah bil ujrah tentu tidak akan berbenturan dengan ketentuan UCP 600 artikel 4 poin a di atas yang menyatakan bahwa bank "tidak tunduk pada tuntutan atau pembelaan-pembelaan applicant yang berasal dari hubungannya dengan issuing bank atau beneficiary", issuing bank hanya bertindak sebagai wakil dari applicant.

Mengenai kekhawatiran jual beli tersebut adalah jual beli objek yang dilarang syariah itu tidak akan terjadi karena L/C impor syariah dengan akad wakalah bil ujrah akan terjadi jika objek yang diperjual-belikan disini bukanlah barang yang dilarang dalam syariah Islam. Mengenai halal tidaknya barang yang diperjualbelikan akan terlihat dari Harmonise System (HS) Number barang tersebut. Barang-barang yang halal akan dikenal HS Number-nya. Ketika memang barang yang diperjualbelikan sudah diketahui dan diyakini kehalalannya. Issuing bank harus menjalankan amanahnya dalam lalu lintas pembayaran dengan baik, sebagaimana yang diterangkan dalam Al-Qur'an surat An Nisa ayat 58 .

"Sesungguhnya Allah menyuruh kamu menyampaikan amanat kepada yang berhak menerimanya, dan (menyuruh kamu) apabila menetapkan hukum di antara manusia supaya kamu menetapkan dengan adil. Sesungguhnya Allah memberi pengajaran yang sebaikbaiknya kepadamu. Sesungguhnya Allah adalah Maha mendengar lagi Maha melihat."

Kemudian Al Qur'an Surat Al Anfal ayat 27: "Hai orang-orang yang beriman, janganlah kamu mengkhianati Allah dan Rasul (Muhammad) dan (juga) janganlah kamu mengkhianati amanat-amanat 
yang dipercayakan kepadamu, sedang kamu mengetahui."

dan Al Qur'an Surat Al Mu'minun ayat 7-10

"Dan orang-orang yang
memelihara amanat-amanat (yang
dipikulnya) dan janjinya. Dan
orang-orang yang memelihara
sembahyangnya. Mereka Itulah
orang-orang yang akan mewarisi,
(yakni) yang akan mewarisi syurga
Firdaus. Mereka kekal di
dalamnya."

Alternatif lain yang bisa terjadi adalah karena issuing bank menerbitkan L/C impor Syariah, maka seharusnya UCP 600 mengakomadasi kebutuhan pelaku ekonomi muslim tersebut dengan menjadikan issuing bank dan negotiating bank sebagai satu kesatuan wakil yang menghubungkan antara applicant dan beneficiary. Artinya segala kesepakatan jual beli ada pada applicant dan beneficiary sedangkan issuing bank dan negotiating bank hanya wakil yang menghubungkan antara applicant dengan beneficiary dan tunduk pada ketentuan dari kesepakatan dari applicant dan beneficiary.

Dengan menjadikan issuing bank dan negotiating bank sebagai satu kesatuan wakil, maka ketentuan ini akan sesuai dengan aturan yang tertera pada artikel 4 poin a tersebut. Adapun mengenai bagaimana porsi ujrah yang akan diterima oleh issuing bank dan negotiating bank harus dihitung secara adil berdasarkan kesepakatan kedua bank tersebut.

Namun disini, karena bank hanya bertindak sebagai wakil dalam lalu lintas pembayaran saja, dan tidak ikut ambil bagian dalam pengecekan barang. Maka disini akan berpotensi terjadi penipuan yang dilakukan oleh eksportir dan importir. Yaitu ketidaksesuaian antara dokumen barang yang diserahkan kepada bank dengan barang yang dikirimkan. Dan yang lebih parahnya barang tersebut adalah barang yang dilarang dalam syariah Islam.
Untuk menghindari terjadinya penipuan yang dilakukan oleh eksportir dan importir, maka sebaiknya UCP mengatur keterlibatan bank dalam pengecekan barang. Untuk lebih jelasnya hubungan bank dengan barang akan dijelaskan pada pembahasan artikel 5.

Poin b dalam artikel 4 UCP600, yang berbunyi:

"Beneficiary sama sekali tidak dapat mengikatkan dirinya atas hubungan-hubungan

kontraktual antar bank-bank atau antara applicant dan issuing bank"

Pernyataan ini tidak bermasalah karena hubungan kontraktual antar bank dan hubungan kontraktual antara applicant dengan issuing bank terjadi tanpa campur tangan beneficiary, apakah itu pada akad wakalah bil ujrah yang terjadi di awal atau pada keadaan alternatif kedua.

\section{Analisis Issuing Bank sebagai Pembeli Tunggal atau Berserikat dengan Applicantsebagai Pembeli pada Akad Murabahah atau Musyarakah}

Lain halnya dengan akad murabahah atau musyarakah pada L/C impor syariah. Dalam akad murabahah atau musyarakah pada L/C impor syariah, jelaslah bahwa bank bertindak sebagai pembeli menggantikan applicant yang tidak memiliki kecukupan dana walaupun secara praktik tetaplah applicant mewakili issuing bank melakukan kontrak jual beli dan kontrak jual beli tersebut ditulis atas nama applicant. Sehingga kalimat yang berbunyi, "Bank-bank sama sekali tidak memperhatikan atau terikat oleh kontrak..." tidak sesuai dengan akad murabahah pada L/C impor ini. Karena dalam hal ini jelas, bahwa secara hakikat issuing bank berperan sebagai pembeli, namun applicant yang mewakili issuing bank dalam kontrak jual beli. 
Selain itu, kontrak jual beli yang dilakukan oleh applicant dengan beneficiary mencantumkan nama-nama bank yang akan dijadikan sebagai perwakilan dalam lalu lintas pembayaran. Berdasarkan hukum kontrak yang bernuansa Islam, kontrak akan sah jika pihak-pihak yang tercantum dalam kontrak tersebut setuju untuk mengikatkan diri.( Ahmad, 2012 ) Sehingga artikel 4 poin b yang berbunyi:

"Beneficiary sama sekali tidak dapat mengikatkan dirinya atas hubungan-hubungan kontraktual antar bank-bank atau antara applicant dan issuing bank" Akan bertentangan dengan hukum kontrak dalam nuansa Islam. Karena dalam kontrak disebutkan pihakpihak yang terlibat dalam jual beli tersebut. Sehingga otomatis semua pihak (applicant, beneficiary, issuing bank dan negotiating bank) saling terikat satu sama lain.

\section{Artikel 5 UCP 600}

Artikel 5 berkaitan dengan Dokumen versus barang, jasa atau pelaksanaan yang berbunyi: "Dokumen VS Barang, Pelayanan atau Kinerja Bank-bank berurusan dengan dokumen-dokumen dan tidak dengan barang, jasa atau pelaksanaan terhadap mana dokumen-dokumen tersebut mungkin berkaitan." Analisis dari Artikel di atas adalah sebagai berikut.

\section{Analisis Issuing Banksebagai Wakil dari Applicantdalam Lalu lintas Pembayaran}

Melihat artikel 5 di atas, jika kita menghubungkan dengan syarat wakalah yang dipaparkan dalam fatwa DSN NO: 10/DSN-MUI/IV/2000, hal-hal yang diwakilkan dalam wakalah diantaranya tidak boleh bertentangan dengan syariat Islam. Dengan keluarnya fatwa DSN tentang L/C impor syariah, maka applicant yang ingin menggunakan L/C impor syariah pun harus memenuhi kriteria objek yang diperjual-belikan tidak boleh bertentangan dengan syariat Islam. L/C impor syariah hanya akan terbit pada transaksi perdagangan produk yang tidak dilarang syariah. Sebagaimana yang diharamkan untuk dikonsumsi dalam AlQur'an Surat Al Maidah ayat 3.

Akad wakalah bil ujrah memang akan sesuai dengan aturan dalam artikel 5 UCP 600 tersebut. Karena amanah yang diberikan kepada issuing bank hanyalah sebatas dalam lalu lintas pembayaran. Namun dengan tidak adanya campur tangan sedikit pun issuing bank atau negotiating bank dalam pengecekan barang, maka disini terdapat peluang terjadinya penipuan yaitu ketidaksesuaian antara barang yang diperjual belikan dengan dokumen barang.

Kemungkinan ini dapat terjadi karena besaran ujrah L/C pada bank syariah relatif lebih murah dibandingkan dengan biaya L/C pada bank konvensional. Pihak-pihak yang curang bisa saja memanfaatkan kondisi ini dalam menyalahgunakan jasa penerbitan $\mathrm{L} / \mathrm{C}$ di bank syariah untuk jual beli barang tertentu,dimana penjual dan pembeli bertindak curang menipu bank syariah tidak akan disamakan dengan dokumen barang dengan alasan tertentu misalnya objek jual beli tersebut dilarang oleh syariah. Padahal Allah melarang perbuatan curang tersebut sebagaimana dalam firman-Nya dalam Al-Qur'an:

Q.S. Al Muthaffifin : 1-7

"(1) Kecelakaan besarlah bagi orang-orang yang curang, (2) (yaitu) orang-orang yang apabila menerima takaran dari orang lain mereka minta dipenuhi, (3) dan apabila mereka menakar atau menimbang untuk orang lain, mereka mengurangi. (4) Tidaklah orang-orang itu menyangka, bahwa Sesungguhnya mereka akan dibangkitkan, (5) pada suatu hari yang besar, (6) (yaitu) hari (ketika) manusia berdiri menghadap Tuhan semesta alam? (7) sekali-kali jangan curang, karena Sesungguhnya kitab orang yang durhaka tersimpan dalam sijjin." 
Dan larangan menipu dalam jual beli yang diterangkan dalam hadits berikut: Hadis riwayat Ibnu Umar Radhiyallahu'anhu: "Seorang lelaki melaporkan kepada Rasulullah Shallallahu alaihi wassalam. bahwa ia tertipu dalam jual beli. Maka Rasulullah Shallallahu alaihi wassalam. bersabda: Katakanlah kepada orang yang kamu ajak berjual-beli: Tidak boleh menipu! Sejak itu jika ia bertransaksi jual beli, ia berkata: Tidak boleh menipu!." (Shahih Muslim No.2826)

Sehingga jalan peluang terjadinya penipuan seperti ini harus ditutup, sesuai dengan kaidah:

(Bahaya dicegah sebisa mungkin (Karim, 2008 )

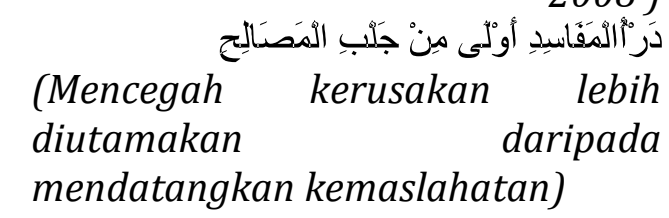

Dengan dibuat aturan yang
mengharuskan issuing bank atau
negotiating bank dalam pemeriksaan
barang, maka penipuan dapat dicegah.

\section{Analisis Issuing Bank sebagai Pembeli Tunggal atau Berserikat dengan Applicant sebagai Pembeli pada Akad Murabahah atau Musyarakah}

Permasalahan juga akan muncul ketika Issuing bank bertindak sebagai pembeli yaitu dengan menggunakan akad murabahah atau musyarakah. Karena issuing bank bertindak sebagai pembeli, sesuai dengan kebutuhan syariah penjualan dianggap sah apabila keberadaan dan kondisi barang harus diperiksa oleh pembeli dan dikonfirmasi oleh penjual. ( International Shari'ah, 2012 ). Sehingga dalam kasus issuing bank sebagai pembeli, berarti issuing bank harus memastikan keberadaan dan kondisi barang (Sharifah, 2013 ). Untuk keefisienan dan keefektifan, bank akan mewakilkan kepada applicant untuk melakukan pemeriksaan barang dan mencocokkannya dengan dokumen barang.

Namun sebagaimana yang telah dibahas pada kondisi dimana ketika bank tidak ikut langsung dalam pemeriksaan barang, berpeluang terjadi penipuan yang dilakukan atas kerja sama applicant dan beneficiary. Yaitu barang yang diperjualbelikan tidak sesuai dengan dokumen barang. Sehingga perlu diterapkan aturan yang mengharuskan issuing bank atau negotiating bank untuk ikut serta dalam pemeriksaan barang.

Memang jika terjadi ketidaksesuian jenis barang yang tiba di negara asal importir dengan dokumen barang, maka importir tidak akan bisa mengambil barang tersebut karena tidak akan mendapat izin dari bea cukai. Namun, disini juga terdapat peluang untuk melakukan penyuapan oleh importir kepada petugas bea cukai. Sehingga untuk menghindari bentuk penipuan dan penyuapan seperti di atas perlu diberlakukan aturan dalam UCP 600 yang mengharuskan issuing bank atau negotiating bank untuk ikut serta dalam pemeriksaan barang.

\section{Artikel 7 UCP 600}

Artikel 7 UCP 600 tersebut berbunyi:

"Tanggung Jawab Issuing Bank

a. Sepanjang bahwa dokumendokumen yang disyaratkan dipresentasikan kepada nominated bank atau kepada issuing bank dan dokumen-dokumen tersebut merupakan presentasi yang sesuai, issuing bank wajib membayar, apabila credit tersedia dengan :

i. pembayaran atas unjuk, pembayaran yang ditangguhkan atau akseptasi pada issuing bank.

ii. pembayaran atas unjuk pada nominated bank dan nominated bank dimaksud tidak membayar.

iii. pembayaran yang ditangguhkan pada nominated bank dan nominated bank dimaksud tidak menaggung janji pembayaran yang ditangguhan atau, telah menanggung janji pembayaran yang ditangguhkan, tidak membayar pada saat jatuh tempo. 
iv. akseptasi pada nominated bank dan nominated bank dimaksud tidak mengaksep draft yang ditarik atasnya, tidak membayar pada saat jatuh tempo.

v. negosiasi pada nominated bank dan nominated bank dimaksud tidak menegosiasi.

Dengan berpedoman kepada UCP 600 ini bank akhirnya berurusan dengan dokumen saja dan tidak berurusan dengan barang, jasa atau kinerja yang berhubungan dengan dokumen. Setiap perselisihan antara pembeli dan penjual harus diselesaikan di antara mereka . Bank harus membayar kepada benefiary setelah dokumen yang dipresentasikan sesuai, terlepas dari apakah pembeli mampu atau tidak mampu membayar. ( Rosmawan, 2013 ).

Oleh karena itu, issuing bank harus membayar kepada beneficiary saat dokumen yang dikirimkan sesuai dengan permintaan pada L/C yang diterbitkan untuk applicant bahkan jika beneficiary tidak mengirimkan barang, barang yang dikirim berkualitas buruk, atau benarbenar berbeda dari deskripsi kontrak .

Pada artikel 7 poin a di atas, disebutkan bahwa bank wajib membayar jika dokumen yang dipresentasikan sesuai. Ketika dokumen barang diterima oleh issuing bank dari negotiating bank dan sesuai maka issuing bank wajib membayar harga yang telah disepakati. Ini kaitannya dengan jenis sight $L / C$ yang sudah difatwakan boleh oleh DSN MUI. Namun alangkah baiknya jika pembayaran dilakukan setelah pembeli memeriksa keberadaan dan kondisi barang.

\section{Artikel 13 UCP 600}

Artikel 13 UCP 600 berbunyi:

"Aturan Reimbursemen Antar Bank

b. Jika credit tidak menyatakan bahwa reimbursemen tunduk pada ketentuan ICC untuk reimbursemen antar bank, yang berikut berlaku ; iii. Issuing bank akan bertanggung jawab atas setiap kerugian bunga, dan juga pengeluaran yang ditanggung, jika reimbursement tidak diberikan pada permintaan pertama oleh reimbursing bank sesuai dengan syarat dan kondisi credit.

Pada Artiel 13 poin b iii di atas, disebutkan bahwa Issuing bank harus bertanggung-jawab atas kerugian bunga jika reimbursement tidak diberikan pada permintaan pertama oleh reimbursing bank sesuai dengan syarat dan kondisi kredit. Ini berlaku baik saat issuing bank bertindak sebagai wakil maupun bertindak sebagai pembeli. Padahal bunga secara tegas dilarang oleh syariah Islam. Karena bunga termasuk ke dalam salah satu jenis riba. Sebagaimana Allah berfirman dalam Al-Qur'an Surat AlBaqarah ayat 275 tentang pelarangan riba.

".... Padahal Allah telah menghalalkan jual beli dan mengharamkan riba...." Kemudian hadits Rasulullah yang tentang riba:

Dari Usamah bin Zaid radhiyallahu'anhu: "Bahwa Nabi Shallallahu alaihi wassalam. bersabda: 'Sesungguhnya riba itu hanya terdapat pada penundaan pembayaran.'” (Shahih Muslim No.2991)

\section{Artikel 16 UCP 600}

Artikel 16 UCP 600 berbunyi:

“Dokumen Diskrepansi, Persetujuan Dan Pemberitahuan

g. Bilamana issuing bank menolak untuk membayar atau confirming bank menolak untuk membayar atau menegosiasi dan telah memberikan pemberitahuan untuk tujuan itu sesuai dengan pasal ini, bank tersebut kemudian berhak menuntut pembayaran kembali, dengan bunga, atas setiap reimbursemen yang dilakukan."

Sama dengan pembahasan sebelumnya bahwa saat issuing bank bertindak sebagai wakil maupun saat bank 
bertindak sebagai pembeli, pada artikel 16 poin $\mathrm{g}$ di atas, issuing bank tidak boleh menerima bunga atas tuntutan pembayaran kembali jika dokumen barang tidak sesuai dan issuing bank menolak untuk membayar. Mengenai dalil keharaman bunga itu sendiri telah disampaikan pada pembahasan sebelumnya.

\section{KESIMPULAN DAN IMPLIKASI}

Berdasarkan penelitian yang dilakukan oleh peneliti, hal yang dapat peneliti simpulkan adalah bahwa:

1. DSN MUI telah melakukan upaya untuk mengakomodasi umat Islam yang ingin melakukan perdagangan internasional dengan cara mengeluarkan fatwa $\mathrm{L} / \mathrm{C}$ impor syariah No.34 dan L/C ekspor syariah No. 35. Namun langkah DSN ini terbentur oleh aturan perdagangan internasional UCP 600 yang notabene adalah produk konvensional. Dan jelas disini UCP 600 dibuat berdasarkan kebutuhan dari L/C konvensional.

2. Berkaitan dengan itu, aturan konvensional bukan berarti tidak sesuai dengan aturan Islam. Penulis menyimpulkan bahwa sebagian besar aturan yang disebutkan dalam artikelartikel UCP 600 tidak bertentangan dengan syariah. Hanya terdapat beberapa artikel yang dianggap peneliti tidak sesuai dengan aturan syariah. Artikel-artikel tersebut adalah sebagai berikut:

a. Artikel 4, yaitu yang menjadi permasalahan disini bahwa bank tidak terikat kontrak jual beli. Jika L/C yang digunakan menggunakan akad murabahah maka aturan ini tidak akan bisa mengakomodasi L/C tersebut. Karena kontrak jual beli dalam Islam adalah mengikat semua pihak yang tertera dalam kontrak tersebut.

b. Artikel 5, yaitu yang menjadi permasalahan disini adalah bank tidak berurusan dengan barang hanya berurusan dengan dokumen. Sama halnya jika akad murabahah yang dipakai dalam L/C tersebut, maka bank tentu mempunyai hak untuk berurusan dengan barang, walaupun bank tidak harus secara langsung berurusan dengan barang tersebut.

c. Artikel 7 yaitu issuing bank berkewajiban membayar ketika menerima dokumen barang dari negotiating bank dan dokumen tersebut cocok dengan apa yang diminta dalam L/C (fully complied with). Padahal untuk mencegah terjadinya penipuan, alangkah baiknya jika pembayaran dilakukan setelah dilakukan pengecekan keberadaan dan kondisi oleh pembeli.

d. Artikel 13 yaitu issuing bank harus membayar denda bunga jika reimbursement tidak diberikan pada permintaan pertama oleh reimbursing bank sesuai dengan syarat dan kondisi kredit. Dan bunga adalah salah satu jenis riba yang dihukumi haram dalam syariah Islam.

e. Artikel 16 yaitu issuing bank akan menerima bunga atas tuntutan pembayaran kembali jika dokumen barang tidak sesuai dan issuing bank menolak untuk membayar. Dan bunga adalah salah satu jenis riba yang dihukumi haram dalam syariah Islam.

\section{DAFTAR PUSTAKA}

Black, Henry Campbell. 1979. Black's Law Dictionary, $5^{\text {th }}$ Ed. USA: West Publishing Co.

Chapra, M. Umer. 2001. Towards A Just monetary System terjemahan Ikhwan Abidin Basri dengan judul Terjemahan "Sistem Moneter Islam". Jakarta: Gema insani Press bekerja sama dengan Tazkia Cendekia.

Hasibuan, Malayu S.P. 2009. Dasar-Dasar Perbankan. Jakarta: PT Bumi Aksara.

Internasional Chamber of Commerce. 2007. United Customs and Practices for 
Documentary Credit ICC Publication No. 600 Revision 2007.

International Shari'ah Research Academy for Islamic Finance (ISRA). 2012. Islamic Financial System: Principles and Operations, Kuala Lumpur: ISRA.

Karim, Adiwarman A. 2009. Bank Islam: Analisis Fikih dan Keuangan. Jakarta: PT RajaGrafindo Persada, 2009.

Miru, Ahmadi. 2012. Hukum Kontrak Bernuansa Islam. Jakarta: PT RajaGrafindo Persada.

Nazir, Habib dan Muhammad Hassanuddin, S. Ag. Ensiklopedi Ekonomi dan Perbankan Syariah. Jakarta : Kaki Langit. 2004.

Rosmawani Che Hashim, Ahmad Azam Othman dan Akhtarzaite Abdul Aziz, Principle of Autonomy In Letter of Credit (LC) - An Overview From Legal And Shariah Perspective dipresentasikan pada $4^{\text {th }}$
International Conference On Business And Economic Research (4th ICBER 2013) Proceeding, 2013.

Warsidi. 2003. Ekspor-Impor Terapan. Surabaya: Karya Abditama Suryabaya. Zaidan, Abdul Karim. 2008. Al Wajiz fi Syarhi Al-Qawa'id Al-Fiqhiyyah fi AsySyari'ah al-Islamiyyah Diterjemahkan oleh Muhyiddin Mas Rida dengan judul "Al-Wajiz: 100 Kaidah Fikih Dalam Kehidupan Sehari-hari". Jakarta: Pustaka Al Kautsar.

Sharifah, Alwi, Faigah Syed, Ibrahim, Uzaimah \& Sawari, Mohd Fuad. 2013. An Issue Uniform Customs dan Practice for Documentary Credits (UCP) No 600 for Islamic Letter of Credit dalam Jurnal Internasional Conference on Economics and Business Research 2013 (ICEBR 2013). Published by Elsevier B.V. Selection. 